\section{B A Institute of \\ yk Business Administration \\ 六下 \\ Karachi \\ Leadership and Ideas for Tomorrow}

Business Review

Volume 14 Issue 1 January-June 2019

$1-1-2019$

\title{
Providing protection for better outcomes: The need for boundary walls at schools in Pakistan
}

\author{
Abbas Ali Gillani \\ Institute of Business Administration, Karachi, Pakistan
}

Follow this and additional works at: https://ir.iba.edu.pk/businessreview

Part of the Finance Commons, Management Sciences and Quantitative Methods Commons, and the Marketing Commons

(c) (7)

This work is licensed under a Creative Commons Attribution 4.0 International License.

\section{Recommended Citation}

Gillani, A. A. (2019). Providing protection for better outcomes: The need for boundary walls at schools in Pakistan. Business Review, 14(1), 1-11. Retrieved from https://doi.org/10.54784/1990-6587.1021

This article is brought to you by iRepository for open access under the Creative Commons Attribution 4.0 License and is available at https://ir.iba.edu.pk/businessreview/vol14/iss1/1. For more information, please contact irepository@iba.edu.pk. 


\title{
Providing protection for better outcomes: The need for boundary walls at schools in Pakistan
}

\author{
Abbas Ali Gillani
}

\begin{abstract}
This paper explores the importance of a boundary wall at school as a measure of protection and safety, by testing the correlation between a school having a boundary wall and its total enrolment. By using panel data estimation with year and district fixed effects we find that across all levels of schooling, having a boundary wall was correlated with higher total enrolment. Enrolment at primary, middle and high school was 4.0 per cent, 2.3 per cent and 3.0 per cent higher. Gender-wise breakup of the results shows similar correlation for both boys and girls at primary level. However, at middle and high school level, the correlation between boundary wall and total enrolment was only significant for girls.
\end{abstract}

Keywords Enrolment · Boundary wall · Protection.

\section{Introduction}

The attack on Army Public School in Peshawar, Pakistan, which left more than 140 people dead, including more than 130 students, is described as one of the worst terror attacks involving children (Telegraph 2014). In the aftermath of the attack, the government of Pakistan decided to increase the security of schools as part of its National Action Plan, which included the clause 'the minimum height of boundary wall of each institution should be at least eight feet high with barbed wire on top of it' (Tribune, 2015). This means that the government itself was of the opinion that safeguarding schools with the presence of an adequate boundary wall would help avert attacks on schools and make them a safer place.

Boundary walls at schools, especially in countries where attacks on educational institution are on a rise, and community level violence is increasing, have continued to serve as a necessary measure for safety and protection for students. It restricts the unregulated movement of individuals in and out of school, and limits the access of unknown people entering school without seeking permission

Abbas Ali Gillani

Institute of Business Administration, University Road, Karachi-Pakistan

E-mail: aagillani@iba.edu.pk 


\section{A. Gillani}

or informing concerned authorities. The need of a boundary wall at school, like other facilities such as toilets, classroom furniture, drinking water and learning material is considered as a basic element of school infrastructure needed for better learning and improved educational outcomes of students. Moreover, in a lot of instances, even though the threat of violence or attack on school might be limited, boundary wall serves as a protection for students against injuries and accidents when schools are located at vulnerable locations, example next to heavy traffic points, riversides, construction sites etc. Furthermore, boundary walls do not only give a sense of security to students and individuals present in school, but also provide comfort to parents for sending their children to school. The presence of a boundary wall may reduce anxiety and fear amongst parents about the wellbeing of their children, especially if they consider the school premises to be vulnerable to threats.

This paper aims at finding the link between boundary walls and total enrolment of schools, by comparing schools that have a boundary wall with schools that do not have a boundary wall. By analysing individual school level data in Pakistan between the year 2012 till 2017, we estimate whether having a boundary wall at school was correlated with higher school enrolment. By using a panel data estimation and controlling for year and district fixed effects, we find that schools that had a boundary wall had a 3.9 per cent higher total enrolment compared to schools that did not have a boundary wall.

The results are consistent across all three levels of schooling. At primary level, having a boundary wall was correlated with higher enrolment, with schools that had a boundary wall having 4.0 per cent higher enrolment compared to schools that did not have a boundary wall. Similarly, at middle and high school level, enrolment of schools that had a boundary wall was 2.3 per cent and 3.9 per cent higher respectively compared to schools that did not have a boundary wall. A gender-wise breakup of results suggests that at primary level, having a boundary wall was correlated with higher enrolment for both boys and girls. However, the relationship is only evident for girls, and not for boys, at middle and high school level.

The remainder of the paper is structured as follows: Section 2 provides a review of the relevant literature that exists on the impact of varying school infrastructure on educational outcomes. Section 3 describes the datasets used for this research and section 4 discusses the identification strategies applied for our estimations. Results are presented in section 5 while section 6 concludes the paper.

\section{Literature review}

There is ample evidence that suggests how school's learning environment and physical infrastructure plays a significant role in educational outcomes and attainment, including enrolment, test scores and student performance. Schneider (2002) explores the school facility attributes that affect academic outcomes the most and in what manner and degree. Examining six categories of indoor air quality, ventilation and thermal comfort; lighting; acoustics; building age and 
quality; school size; and class size, the research concludes that all six categories of school facilities affect learning. School environment including air quality, noise, light and temperature are all linked to students; and teachers' ability to perform.

Moreover, Adesina (1990) examines the relationship between school infrastructure planning and students' academic performance using a descriptive survey research design. Using multistage, stratified and simple random sampling techniques, five null hypotheses are tested for the correlation between academic performance and instructional, administrative, circulation, accessories and convenience space planning. The results suggest that all five categories of infrastructure planning were closely linked to academic performance. Furthermore, Cash (1993) found that comfort factors had a huge role to play in improved student achievement. High achievement was associated with schools that were less noisy, had less graffiti, were air conditioned and where classroom furniture and student lockers were in good repairs. Student scores on achievement tests were found to be 5 percentile points lower in schools with buildings with lower quality ratings.

Other than environment, specific school facilities and physical infrastructure also plays a role in educational outcomes. Bruce (2006) finds that both out-of-class and in-class environment can foster individual learning. The quality of furniture in classroom, specifically chairs, need to be movable, durable and comfortable for the students, and must be child-friendly. Similarly, bookshelves in classrooms, a clock, and a clean environment also helps a child in their learning outcomes. Corcocan et al. (1988) reveal that school buildings are of critical importance to the teaching and learning process, suggesting an effect of physical conditions on teacher morale, personal safety and general learning outcomes. They find that building renovations led to renewed sense of hope and commitment in teachers. Also, broken toilets, leaking roofs and burned out lights were highlighted as the basic factors for a backdrop in learning outcomes. Lastly, Olubor (1998) states that the poor performance of students in examinations can be linked to inadequate facilities in schools including textbooks and ill equipped laboratories and libraries.

This research contributes to the existing literature in two distinct ways. Firstly, this study is amongst the first that categorically highlights the importance of boundary walls on enrolment rates. Up till now, most research has focused on impact of school characteristics such as school building, toilets, classrooms, class size etc. on student performance and learning outcomes. This research will be the first that focuses on the importance of having a boundary wall at school as a necessary feature to encourage schooling, and improve enrolment. Secondly, the mechanism for the importance of boundary wall highlighted in this study is extremely important and relevant in countries like Pakistan, where schools are often under attack and students generally suffer anxiety and fear regarding their security at school. By serving as a protective measure against external threats and violence, this research emphasizes the need of a boundary wall at school as a basic requirement to ensure that students do not feel vulnerable or exposed in a learning environment. 


\section{Data}

Data used for this study is provided by Annual Status of Education Report (ASER). ASER is the largest citizen led, household based initiative in Pakistan that aims to provide reliable estimates on the schooling status of children aged 3-16 years. ASER Pakistan is part of a South-South initiative across India, Kenya, Tanzania, Uganda, Mali, Senegal and Mexico, aimed at addressing quality, accountability and governance in education. ASER is active in 138 out of 145 districts of Pakistan, consistently providing ranked and gender disaggregated data across households, villages, districts and provinces. Each year, 600 households are surveyed per district. 30 villages are selected randomly using the Probability Proportional to Size (PPS) technique from the village directory of the 1998 Census. In each selected village, 20 randomly selected households are surveyed. Every year, 20 villages from the previous year are retained and 10 new villages are added.

Since our research is aimed at analysing the correlation between a school having a boundary wall and total enrolment across Pakistan, we only access data regarding government schools which are present in all rural and urban areas of all districts across Pakistan. Government schools represent almost 85 per cent of all enrolment in Pakistan. Individual level data on one government school surveyed per village in each district is provided from year 2012 till 2016.

This includes data on schools across all provinces of Pakistan, including the Federally Administered Tribal Areas (FATA) and Autonomous Regions of Gilgit, Baltistan and Kashmir. The data reflects essential information on schoollevel indicators such as type of schooling, medium of instruction at school, total enrolment, teacher characteristics, and facilities present at school. A year-wise descriptive statistics of schools surveyed are provided in table 1.

Table 1: Year-wise descriptive statistics of school characteristics

\begin{tabular}{lccccc}
\hline Variable & 2012 & 2013 & 2014 & 2015 & 2016 \\
\hline Average enrolment per school-Overall & 213.3 & 232.9 & 221.6 & 206.9 & 192.8 \\
Share of boys school & 0.3 & 0.54 & 0.5 & 0.33 & 0.35 \\
Share of girls school & 0.54 & 0.16 & 0.18 & 0.51 & 0.48 \\
Share of mixed school & 0.17 & 0.31 & 0.33 & 0.16 & 0.18 \\
Share of english speaking school & 0.23 & 0.23 & 0.22 & 0.19 & 0.16 \\
Share of urdu speaking school & 0.51 & 0.54 & 0.58 & 0.62 & 0.64 \\
Share of other language school & 0.26 & 0.24 & 0.2 & 0.19 & 0.2 \\
Share of 'up till primary' school & - & 0.56 & 0.58 & 0.67 & 0.66 \\
Share of 'up till middle' school & - & 0.16 & 0.15 & 0.12 & 0.14 \\
Share of 'up till high' school & - & 0.2 & 0.18 & 0.15 & 0.16 \\
\hline
\end{tabular}

The descriptive statistics of the schools provides some crucial insight on the data. Firstly, the variation in the share of schools for each gender is considerable across years. Share of boy schools in 2013 and 2015 is more than 50 per cent compared to an average of 33 per cent in 2012, 2015 and 2016. Similarly, share of girl schools drops below 20 per cent in 2013 and 2014 compared to being above 50 per cent in 2012, 2015 and 2016. This variation is primarily attributed 
to the fact that ASER randomly observes one school per village in each district. Depending on the type of school surveyed, it is possible that in certain year boy schools were surveyed more than girl schools, whereas in other years, girl schools were surveyed more compared to boys. Secondly, average enrolment per school is consistent throughout the years. This removes the possibility of any exogenous shocks on schooling witnessed during these years that may have resulted in unexpected changes in enrolment and thus would have biased our results.

Lastly, the share of primary, middle and high school is also consistent across time which suggests that any changes in enrolment would possibly be through changes in demand for schooling and not through unexpected shocks on supply of schooling. We also provide yearwise information on individual school-level characteristics in table 2 .

Table 2: Year-wise descriptive statistics of facilities at school

\begin{tabular}{lccccc}
\hline Variable & 2012 & 2013 & 2014 & 2015 & 2016 \\
\hline Share of schools with boundary walls & 0.68 & 0.66 & 0.69 & 0.72 & 0.73 \\
Share of schools with toilets & 0.6 & 0.6 & 0.61 & 0.62 & 0.63 \\
Share of schools with drinking water & 0.68 & 0.75 & 0.67 & 0.68 & 0.68 \\
Share of schools with playground & 0.43 & 0.43 & 0.43 & 0.46 & 0.45 \\
Share of schools with library books & 0.26 & 0.27 & 0.25 & 0.22 & 0.16 \\
Share of schools with laboratory & 0.16 & 0.18 & 0.18 & 0.16 & 0.34 \\
Share of schools with internet & 0.08 & 0.07 & 0.07 & 0.09 & 0.1 \\
Share of teachers per school with degree & 0.59 & 0.65 & 0.64 & 0.67 & 0.65 \\
Share of teachers per school with training & 0.47 & 0.41 & 0.33 & 0.37 & 0.86 \\
Average number of teachers & 7.6 & 8.2 & 9.5 & 7.4 & 7.1 \\
\hline
\end{tabular}

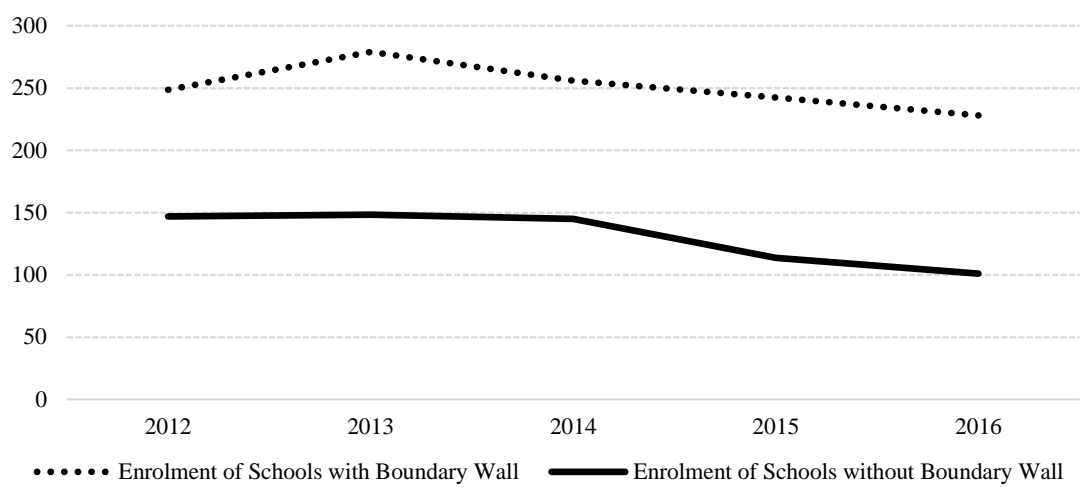

Fig. 1: Comparison of total enrolment of schools with and without boundary walls

Our main estimation strategy focuses on testing the hypothesis that boundary wall serves as a source of security and protection for students, and hence is correlated with higher enrolment in schools. As a result, we show a time-trend comparison of enrolment rates of schools that have a boundary wall with enrol-

Business Review: (2019) 14(1):1-11 


\section{A. Gillani}

ment rates of schools that do not have a boundary wall in figure 1 . We observe that over the years, schools that have a boundary wall consistently have a higher enrolment than schools that do not have a boundary wall.

\section{Empirical methodology}

We estimate the correlation between total enrolment in school and a school having a boundary wall by using a panel data regression and controlling for district and year fixed effects (F.E). We test whether a school that had a boundary wall, compared to a school that did not have a boundary wall, was correlated with higher total enrolment. We estimate:

$$
\log E N R O L_{i, d, t}=\beta_{0}+\delta_{1} W A L L_{i, d, t}+X_{i, d, t}^{\prime}+\gamma_{d}+\eta_{t}+\varepsilon_{i, d, t}
$$

where $E N R O L_{i, d, t}$ is the outcome variable that denotes total enrolment in school $i$ situated in district $d$ in time period $t$, where $t$ equals year 2012 till 2016 . Taking logarithm of enrolment allows for comparing the change in enrolment as a per cent. $W A L L_{i, d, t}$ is a binary variable that equals 1 if school $i$ in district $d$ in time period $t$ had a boundary wall, and equals 0 if school $i$ in district $d$ in time period $t$ did not have a boundary wall. $\delta_{1}$ measures the correlation between a school having a boundary wall and total enrolment.

We control for school specific characteristics which are represented by the control variable $X_{i, d, t}^{\prime}$. The set of controls include three ordinal variables, seven binary variables, two proportional variables and two continuous variables. The ordinal variables include type of school that takes a unique value for whether a school was for boys only, girls only or mixed.

It also includes 'medium of instruction' ordinal that takes a unique value for whether the mode of learning at school (LANG.) was in English, Urdu, or Other language. Finally, an ordinal variable is also included for whether a school was up till primary level (PRIM.), middle level (MID.), or high (HIGH) school level. The seven binary variables control for whether a school had electricity, drinking water, toilet, playground, library books, laboratory and internet. Each of these binary variables equal 1 if the school had the relevant facility, otherwise it equals 0 . Furthermore, the proportional control variables provide us with the share of teachers in each school who had a university degree and share of teachers who had received any formal training in the field of education. Lastly, the continuous variables measure the total number of teachers in each school and the number of years the school has been established. $\varepsilon_{i, d, t}$ is the error term.

For our estimation equation we also include district fixed effects, $\gamma_{d}$, and year fixed effects, $\eta_{t}$, to control for any time-invariant factors that might be correlated with the explanatory binary variable representing boundary walls. These factors might include cultural and social attributes specific to each district that might drive enrolment, or demographics and infrastructure development over time that are unique to each district, or the overall security situation in each district that may shape overall perception about the need of a boundary wall at school. 


\section{Results}

We first provide results for the correlation between school having a boundary wall and enrolment for different levels of schooling. Table 3 suggests that there exists a direct correlation between a school having a boundary wall and higher total enrolment. The results hold true for overall level of schooling, and at different levels of schooling.

Table 3: Overall and school level breakup of correlation between boundary wall and enrolment

\begin{tabular}{|c|c|c|c|c|}
\hline Variables & (1) & (2) & (3) & (4) \\
\hline & All schools & Primary & Middle & High \\
\hline Wall & $\begin{array}{c}0.039 * * * \\
(0.007)\end{array}$ & $\begin{array}{c}0.040^{* * *} \\
(0.008)\end{array}$ & $\begin{array}{c}0.023^{* *} \\
(0.011)\end{array}$ & $\begin{array}{c}0.030^{* * *} \\
(0.011)\end{array}$ \\
\hline School has water & $\begin{array}{c}0.035^{* * *} \\
(0.008)\end{array}$ & $\begin{array}{c}0.046^{* * *} \\
(0.009)\end{array}$ & $\begin{array}{c}0.048^{* * *} \\
(0.012)\end{array}$ & $\begin{array}{c}0.040^{* * * *} \\
(0.013)\end{array}$ \\
\hline School has library & $\begin{array}{c}0.061^{* * *} \\
(0.007)\end{array}$ & $\begin{array}{c}0.065^{* * *} \\
(0.01)\end{array}$ & $\begin{array}{c}0.049^{* * *} \\
(0.01)\end{array}$ & $\begin{array}{c}0.063^{* * * *} \\
(0.01)\end{array}$ \\
\hline School has internet & $\begin{array}{c}0.039 * * * \\
(0.011)\end{array}$ & $\begin{array}{c}0.009 \\
(0.021)\end{array}$ & $\begin{array}{l}0.034^{*} \\
(0.019)\end{array}$ & $\begin{array}{c}0.051^{* * * *} \\
(0.013)\end{array}$ \\
\hline School has toilet & $\begin{array}{c}0.036^{* * *} \\
(0.007)\end{array}$ & $\begin{array}{c}0.033^{* * *} \\
(0.009)\end{array}$ & $\begin{array}{c}0.040^{* * *} \\
(0.012)\end{array}$ & $\begin{array}{c}0.036^{* * * *} \\
(0.012)\end{array}$ \\
\hline School has playground & $\begin{array}{c}0.004 \\
(0.006)\end{array}$ & $\begin{array}{l}-0.008 \\
(0.007)\end{array}$ & $\begin{array}{c}0.015 \\
(0.009)\end{array}$ & $\begin{array}{c}0.015 \\
(0.009)\end{array}$ \\
\hline School has laboratory & $\begin{array}{c}0.017^{*} \\
(0.01)\end{array}$ & $\begin{array}{c}-0.037^{* *} \\
(0.017)\end{array}$ & $\begin{array}{c}0.015 \\
(0.015)\end{array}$ & $\begin{array}{c}0.019 \\
(0.012)\end{array}$ \\
\hline Teacher degree & $\begin{array}{c}0.072^{* * *} \\
(0.01)\end{array}$ & $\begin{array}{c}0.062^{* * *} \\
(0.01)\end{array}$ & $\begin{array}{c}0.097^{* * *} * \\
(0.018)\end{array}$ & $\begin{array}{c}0.131^{* * * *} \\
(0.018)\end{array}$ \\
\hline Teacher training & $\begin{array}{c}0.024^{* * *} \\
(0.006)\end{array}$ & $\begin{array}{c}0.020^{* * *} \\
(0.008)\end{array}$ & $\begin{array}{c}0.030 * * * \\
(0.01)\end{array}$ & $\begin{array}{c}0.031^{* * * *} \\
(0.01)\end{array}$ \\
\hline Number of teachers & $\begin{array}{c}0.025^{* * *} \\
(0.001)\end{array}$ & $\begin{array}{c}0.029^{* * *} \\
(0.002)\end{array}$ & $\begin{array}{c}0.024^{* * *} \\
(0.001)\end{array}$ & $\begin{array}{c}0.019^{* * * *} \\
(0.001)\end{array}$ \\
\hline School established & $\begin{array}{c}0.001^{* * *} * \\
(0.0001)\end{array}$ & $\begin{array}{l}0.00^{* * *} \\
(0.0001)\end{array}$ & $\begin{array}{c}0.001^{* * *} * \\
(0.0002)\end{array}$ & $\begin{array}{c}0.001 * * * \\
(0.0002)\end{array}$ \\
\hline School type & Yes & Yes & Yes & Yes \\
\hline School lang. & Yes & Yes & Yes & Yes \\
\hline District F.E. & Yes & Yes & Yes & Yes \\
\hline Year F.E & Yes & Yes & Yes & Yes \\
\hline R-Squared & 0.59 & 0.53 & 0.57 & 0.65 \\
\hline Observations & 9910 & 6548 & 3411 & 3554 \\
\hline
\end{tabular}

Standard errors in parentheses ${ }^{* * *} \mathrm{p}<0.01,{ }^{* *} \mathrm{p}<0.05,{ }^{*} \mathrm{p}<0.1$

Column (1) suggests that once controlled for all school level characteristics, and district and year fixed effects, having a boundary wall was correlated with a 3.9 per cent higher student enrolment. The results are significant at the 1 per cent level. Moreover, the correlation also holds true when estimates are provided at different level of schooling. Column (2) suggests that once controlled for all school level characteristics, and district and year fixed effects, having a boundary wall at primary schools was correlated with a 4.0 per cent higher student enrolment. The results are significant at the 1 per cent level. Furthermore, col- 


\section{A. Gillani}

umn (3) also suggests a similar correlation between boundary wall and higher enrolment at middle level. Once controlled for all school level characteristics, and district and year fixed effects, having a boundary wall was correlated with a 2.3 per cent higher enrolment at middle school level. The results are significant at the 5 per cent level. Lastly, column (4) also suggests that once controlled for all school level characteristics, and district and year fixed effects, having a boundary wall was correlated with a 3.0 per cent higher enrolment at high school level. The results are significant at the 1 per cent level.

Overall, although our results may slightly vary in magnitude across different level of schoolings, they clearly indicate that having a boundary wall at school is correlated with higher enrolment in school. Since the primary purpose of a boundary wall at school is to protect all individuals in school, including students, this suggests that providing security and safety of students at school is an essential factor in ensuring an overall high level of enrolment at schools. Boundary walls may not only serve as a protective measure against any direct violence against schools, but can also safeguard students against any negative incidence that may be occurring in the community, or in the surroundings of the school. Thus, boundary walls at schools can assist in providing direct protection to students through securing the parameters of school and shielding it from any negative events, and at the same time can provide mental and psychological reassurances to students that they are safe.

We now provide gender-wise breakup of our results at different level of schooling in table 4. Results from column (1) and column (2) in table 4 above show that there exists a direct correlation between primary schools having a boundary wall and higher total enrolment for boys' schools and girls'. Column (1) suggests, that boundary wall at boys' primary school was correlated with a 3.8 per cent higher enrolment, with the results being significant at the 1 per cent level. At the same time, column (2) suggests, that boundary wall girls primary school was correlated with a 4.5 per cent higher enrolment, with the results being significant at the 1 per cent level. This suggest that at primary level, boundary wall served as a security for all students, including boys and girls, which played an important role towards higher primary level enrolment. This has significant policy implications, as many countries, including Pakistan, face a tough task of achieving universal access to primary level education due to challenges on the both the demand and supply side of schooling. Improvements in infrastructure, particularly in boundary walls, would provide a safer environment for children at primary level to gain education, and encourage enrolments for both boys and girls.

However, at middle level, we find that the direct correlation between schools having a boundary wall and higher enrolment is only significant for girls' school, and not for boys' school. Column (3) in table 4 above does show a direct correlation between boundary wall at schools for boys at middle level and total enrolment, but the results are not significant. Hence, we cannot conclude any relationship linking schools having a boundary wall and total enrolment for boys at middle level. On the other hand, results from column (4) in table 4 above does show a significant direct correlation between total enrolment and boundary wall at girls school at middle level. Girls' school at middle level with boundary 
walls were linked to a 3.1 per cent higher total enrolment, the results being significant at the 5 per cent level.

Table 4: Gender-wise breakup of impact of boundary wall on total enrolment

\begin{tabular}{|c|c|c|c|c|c|c|}
\hline & $\begin{array}{l}\text { Prim. } \\
\text { Boys }\end{array}$ & $\begin{array}{l}\text { Prim. } \\
\text { Girls }\end{array}$ & $\begin{array}{l}\text { Mid. } \\
\text { Boys }\end{array}$ & $\begin{array}{l}\text { Mid. } \\
\text { Girls }\end{array}$ & $\begin{array}{l}\text { High } \\
\text { Boys }\end{array}$ & $\begin{array}{l}\text { High } \\
\text { Girls }\end{array}$ \\
\hline Variables & (1) & $(2)$ & (3) & (4) & $(5)$ & (6) \\
\hline Wall & $\begin{array}{c}0.038^{* * *} * \\
(0.013)\end{array}$ & $\begin{array}{c}0.045^{* * *} \\
(0.014)\end{array}$ & $\begin{array}{c}0.006 \\
(0.021)\end{array}$ & $\begin{array}{c}0.031^{* *} \\
(0.016)\end{array}$ & $\begin{array}{c}0.023 \\
(0.019)\end{array}$ & $\begin{array}{c}0.038 * * \\
(0.015)\end{array}$ \\
\hline School has water & $\begin{array}{c}0.060^{* * *} \\
(0.014)\end{array}$ & $\begin{array}{l}0.029^{*} \\
(0.015)\end{array}$ & $\begin{array}{c}0.062^{* *} \\
(0.021)\end{array}$ & $\begin{array}{c}0.038^{* *} \\
(0.018)\end{array}$ & $\begin{array}{c}0.025 \\
(0.021)\end{array}$ & $\begin{array}{c}0.048^{* * *} \\
(0.017)\end{array}$ \\
\hline School has library & $\begin{array}{c}0.060 * * * \\
(0.02)\end{array}$ & $\begin{array}{c}0.082^{* * *} \\
(0.016)\end{array}$ & $\begin{array}{l}0.004 \\
(0.02)\end{array}$ & $\begin{array}{c}0.059^{* * *} * \\
(0.016)\end{array}$ & $\begin{array}{c}0.029 \\
(0.019)\end{array}$ & $\begin{array}{c}0.058^{* * *} * \\
(0.015)\end{array}$ \\
\hline School has internet & $\begin{array}{c}-0.194^{* * *} \\
(0.066)\end{array}$ & $\begin{array}{c}0.04 \\
(0.026)\end{array}$ & $\begin{array}{c}-0.071 \\
(0.063)\end{array}$ & $\begin{array}{c}0.059 * * \\
(0.024)\end{array}$ & $\begin{array}{c}0.015 \\
(0.024)\end{array}$ & $\begin{array}{c}0.052^{* * *} \\
(0.02)\end{array}$ \\
\hline School has toilet & $\begin{array}{c}0.018 \\
(0.014)\end{array}$ & $\begin{array}{c}0.050^{* * *} * \\
(0.015)\end{array}$ & $\begin{array}{c}0.032 \\
(0.021)\end{array}$ & $\begin{array}{c}0.056^{* * *} \\
(0.017)\end{array}$ & $\begin{array}{c}0.040^{* *} \\
(0.02)\end{array}$ & $\begin{array}{c}0.047^{* * *} \\
(0.017)\end{array}$ \\
\hline School has playground & $\begin{array}{l}-0.015 \\
(0.012)\end{array}$ & $\begin{array}{l}-0.004 \\
(0.012)\end{array}$ & $\begin{array}{l}0.029^{*} \\
(0.017)\end{array}$ & $\begin{array}{l}-0.007 \\
(0.014)\end{array}$ & $\begin{array}{c}0.023 \\
(0.015)\end{array}$ & $\begin{array}{c}0.005 \\
(0.014)\end{array}$ \\
\hline School has laboratory & $\begin{array}{c}0.03 \\
(0.042)\end{array}$ & $\begin{array}{c}-0.043^{*} \\
(0.021)\end{array}$ & $\begin{array}{c}0.05 \\
(0.03)\end{array}$ & $\begin{array}{c}0.008 \\
(0.021)\end{array}$ & $\begin{array}{r}-0.003 \\
(0.02)\end{array}$ & $\begin{array}{c}0.040^{* *} \\
(0.017)\end{array}$ \\
\hline Teacher degree & $\begin{array}{c}0.057 * * * \\
(0.016)\end{array}$ & $\begin{array}{c}0.083^{* * *} \\
(0.018)\end{array}$ & $\begin{array}{l}0.042 \\
(0.03)\end{array}$ & $\begin{array}{c}0.109 * * * \\
(0.027)\end{array}$ & $\begin{array}{c}0.100^{* * * *} \\
(0.029)\end{array}$ & $\begin{array}{c}0.130 * * * \\
(0.024)\end{array}$ \\
\hline Teacher training & $\begin{array}{c}0.01 \\
(0.012)\end{array}$ & $\begin{array}{c}0.032^{* * *} \\
(0.013)\end{array}$ & $\begin{array}{c}0.038^{* *} \\
(0.018)\end{array}$ & $\begin{array}{c}0.023^{*} \\
(0.014)\end{array}$ & $\begin{array}{c}0.026 \\
(0.017)\end{array}$ & $\begin{array}{c}0.009 \\
(0.014)\end{array}$ \\
\hline Number of teachers & $\begin{array}{c}0.032^{* * *} * \\
(0.005)\end{array}$ & $\begin{array}{c}0.026^{* * *} \\
(0.002)\end{array}$ & $\begin{array}{c}0.030 * * * \\
(0.003)\end{array}$ & $\begin{array}{c}0.028^{* * *} \\
(0.002)\end{array}$ & $\begin{array}{c}0.021^{* * *} \\
(0.002)\end{array}$ & $\begin{array}{c}0.018^{* * *} * \\
(0.001)\end{array}$ \\
\hline School established & $\begin{array}{c}0.002^{* * *} \\
(0.0003)\end{array}$ & $\begin{array}{c}0.001^{* * * *} \\
(0.0003)\end{array}$ & $\begin{array}{c}0.001^{* * *} \\
(0.0004)\end{array}$ & $\begin{array}{c}0.001^{* * * *} \\
(0.0003)\end{array}$ & $\begin{array}{c}0.001^{* * *} \\
(0.0003)\end{array}$ & $\begin{array}{c}0.001^{* * *} \\
(0.0003)\end{array}$ \\
\hline School lang. & Yes & Yes & Yes & Yes & Yes & Yes \\
\hline District F.E & Yes & Yes & Yes & Yes & Yes & Yes \\
\hline Year F.E & Yes & Yes & Yes & Yes & Yes & Yes \\
\hline R-Squared & 0.48 & 0.63 & 0.59 & 0.63 & 0.69 & 0.64 \\
\hline Observations & 2582 & 2233 & 1145 & 1555 & 1252 & 1648 \\
\hline
\end{tabular}

Standard errors in parentheses ${ }^{* * *} \mathrm{p}<0.01,{ }^{*} \mathrm{p}<0.05,{ }^{*} \mathrm{p}<0.1$

Similar results are also achieved for schools at high school level, whereby a direct correlation is also found between schools having a boundary wall and higher enrolment for both boys and girls, but the results are only significant for girls' school. Boundary wall and higher enrolment is only significant for girls' school, and not for boys' school. Column (5) in table 4 above does show a direct correlation between boundary wall at schools for boys at high school level and total enrolment, but the results are not significant. Thus, we cannot conclude any relationship linking schools having a boundary wall and total enrolment for boys at high school level. On the other hand, results from column (6) in table 4 above does show a significant direct correlation between total enrolment and boundary wall at girls school at high school level. Girls' school at high school level with boundary walls were linked to a 3.8 per cent higher total enrolment, the results being significant at the 5 per cent level.

Business Review: (2019) 14(1):1-11 


\section{A. Gillani}

The significant correlation between schools having a boundary wall and higher enrolment for girls at middle and high school specifically raises an important concern regarding safety of girls going to school and the considerable restrictions to access to education that girls face in Pakistan. Amongst the many social and cultural norms that prohibit girls from going to school after primary level, the rising security concern for safety of girls is one of the major factors that contribute to limited enrolment of girls in schools. Girls in Pakistan face many sorts of security threats from outside and within school that lead to girls dropping out of school. Kidnapping, harassment, crime and attacks specifically targeted towards girls in Pakistan in recent years has led to a feeling of insecurity and a fear amongst girls from going to school.

Of the hundreds of schools attacked in Pakistan between 2013 and 2017, one third of these attacks were specifically targeted towards girls and women, aiming to interrupt their studies (Human Rights Watch, 2018). Girls and families don't only fear for the security of girls in school, but also worry about their well-being when they are vulnerable to attacks outside school. Without a boundary wall, girls feel exposed and vulnerable to any threat, physical or psychological, which results in them dropping out of school altogether. Many parents decide not to permit their daughters to go to school when they do not feel a sense of security towards their daughters, and consider their daughters to be unsafe in a risky environment. For these reasons, it is therefore only appropriate, that we find a significant correlation between schools having a boundary wall and higher total enrolment for girls, and not boys, at middle and high school level.

\section{Conclusion}

By analysing individual school level data in Pakistan, we estimate whether having a boundary wall at school was correlated with higher school enrolment. By using a panel data estimation and controlling for year and district fixed effects, we find that having a boundary wall at school was linked to a 3.9 per cent higher overall enrolment. The results are consistent across primary, middle and high school level. A gender-wise breakup of results suggests that at primary level, having a boundary wall was correlated with higher enrolment for both boys and girls. However, the relationship is only evident for girls, and not for boys, at middle and high school level.

This research has several policy implications and highlights key issues to be addressed by future policymakers. Firstly, although due to the limitation of the data, this paper does not explore the causal relationship between presence of a boundary wall leading to higher school enrolment, it does establish a correlation between schools having a boundary wall and higher enrolment. This suggest that providing a sense of security and safety to students does lead to a higher demand for schooling. Students, parents and community members in general feel protected sending children to school when a school is deemed safe.

Secondly, in many parts of the world, cultural norms and values have limited access to education for girls anyways. Governments and policymakers must pay particular attention towards factors contributing to the limited access, and pro- 
vide better incentives and favourable environment to encourage girls towards going to school. Security concerns for safety of girls in many parts of the world is still one of the major factors that contribute to limited enrolment of girls in schools. Lastly, even from the supply side of schooling, plenty of focus has been directed towards improving infrastructure and learning environment of schools. However, very little empirical work has been done on the different mechanisms through which safer school premises, particularly inclusion of adequate school boundary walls, can lead to improved learning outcomes and higher educational attainment.

\section{References}

Adesina, S. (1990). Educational Management' Enugu: 4th Dimensional Publishers Co. Ltd.

Corcoran, T. B., Walker, L. J., \& White, J.L. (1988). Working in urban schools. Washingtond D.C.: Institute for Educational Leadership.

Avenue, H.R.W.- 350 F., York, 34th Floor - New, t 1.212.290.4700, N. 101183299 U.- , 2018. Shall I Feed My Daughter, or Educate Her? Barriers to Girls' Education in Pakistan [WWW Document]. Human Rights Watch.

URL https://www.hrw.org/report/2018/11/12/shall-i-feed-my-daughter-oreducateher/barriers-girls-education-pakistan (accessed 3.3.19).

Bruce, T. (2006). Early Childhood Education: A guide for students. London: SAGE Publications.

Cash, C. (1993). A Study of the Relationship between School Building Condition and Student Achievement and Behavior. Unpublished doctoral dissertation, Virginia Polytechnic Institute and State University.

Olubor, R.O. (1998). Problems of learning in Public Today Secondary Schools: Implications for Homes and Schools in the Nigerian Teachers. J. Teacher Edu. NCCE, Kaduna, 6 (1): 222-226.

Schneider, M. (2002). Do school facilities affect academic outcomes? National Clearinghouse for Educational Facilities.

Size matters: School managements told to raise boundary walls [WWW Document], 2015. The Express Tribune. URL https://tribune.com.pk/story/866606/sizematters-school-managements-told-toraise-boundary-walls.

Taliban kill more than 100 children in Pakistan school attack [WWW Document], 2014. The Telegraph. URL

https://www.telegraph.co.uk/news/worldnews/asia/pakistan/11295865/Talibankillat-least-100-children-in-school-attack-in-Pakistan.html.

Welcome To ASER Pakistan - Education in Pakistan - Annual Status of Education Report [WWW Document]. URL http://aserpakistan.org/index.php 